\title{
The Influence of Rhizobacteria that Promotes Growth of Plants on the Nutritional Acquisition Process
}

\section{Harsha Sharma ${ }^{1}$ and Avadhesh Kumar Koshal ${ }^{2 *}$}

${ }^{1}$ Assistant Professor, Faculty of Science, Motherhood University, Roorkee, Uttarakhand, India

${ }^{2}$ Professor, Faculty of Science, Motherhood University, Roorkee, Uttarakhand, India

*Corresponding Author: Avadhesh Kumar Koshal, Professor, Faculty of Science, Motherhood University, Roorkee, Uttarakhand, India.
Received: October 06, 2021

Published: December 10, 2021

(C) All rights are reserved by Harsha Sharma and Avadhesh Kumar Koshal.

\begin{abstract}
Plant growth-promoting rhizobacteria (PGPR) are soil bacteria that colonise the rhizosphere and promote plant growth through a range of mechanisms including organic matter mineralization, biological control of soil-borne diseases, biological nitrogen fixation, and root growth promotion. The ability of PGPR to enhance nutrient bioavailability is a crucial characteristic. Several bacterial species have been reported as P-solubilizing microorganisms, while others, such as those that create siderophores for Fe chelation, have been found to boost the solubility of micronutrients. The increased concentration of soluble macro and micronutrients along the soilroot interface has a beneficial effect on the plant nutrition. Furthermore, several pieces of evidence suggest that culturing plants with PGPR can have considerable physiological and molecular effects on plants (e.g., induction of rhizosphere acidification, up-and down regulation of genes involved in ion uptake and translocation), suggesting that soil biota could stimulate plants to be more efficient in trying to extract nutrients from soil and coping with abiotic stresses. However, the molecular mechanisms behind these events, the signals involved, as well as their potential uses in a sustainable agriculture strategy and biotechnological elements for hypothetical rhizosphere engineering, are all still up for debate.
\end{abstract}

Keywords: Biotechnology; Iron; Nitrogen; PGPR; Soil Bacteria

\section{Introduction}

Maintaining high agricultural production in the face of rising global food demand for a growing population and natural resource depletion has become a key problem for both developed and developing countries [1]. Traditional nutrient management has primarily relied on external fertiliser inputs to maintain high crop output. However, crop yield has not increased proportionally with growing fertiliser inputs in recent decades, resulting in low nutrient use efficiency and increased environmental concerns.

As a result, overcoming this obstacle entails increasing crop nutrient use efficiency by utilising the inherent biological potential of rhizosphere activities [2]. Rhizo depositions, which include low molecular weight (LMW: organic acids, amino acids, sugars, phenolic acids, flavonoids, etc.) and high molecular weight (HMW: carbohydrates, enzymes, etc.) organic compounds produced by roots, are one of the key driving forces of rhizosphere processes. This is most likely due to the increased growth of bacteria in the root proximity, as well as the chemo attractant activity of LMW root exudates, which make schemotaxis and motility essential traits for plant development [3].

\section{Pseudomonas aeruginosa}

Pathogenic bacteria can produce metabolites that are poisonous to plants in negative interactions, resulting in negative impacts on overall plant growth. Different bacteria can cause favourable effects on plant development and fitness when they are linked with roots; these bacteria are known as plant growth-promoting rhizobacteria (PGPR) [4]. 
They can colonise the host vigorously and boost plant development, either indirectly (as biocontrol agents) or directly (by improving nutrient uptake). The colonisation of the rhizosphere compartment is the consequence of a complicated signal exchange between the two partners, and it determines the type of interaction between them, which can be harmful, neutral, or favourable to plants [5].

Vitamins are a developing class of organic compounds that are actively involved in the plant/bacteria interaction and/or the growth promotion mechanism, in addition to the already identified chemicals involved in the crosstalk between plant and rhizobacteria. Even though the effects of PGPR on plant development and biocontrol have been extensively investigated, the roles of these bacteria in the plant nutrient acquisition process and the molecular mechanisms underpinning the nutritional processes occurring at the rhizoplane have yet to be fully examined. Concentrate on the interactions between plants and rhizobacteria that affect plant mineral feeding in this review. N, P, and Fe are the most important macro and micronutrients, as they are the most responsible for agricultural productivity limitations over the world [6].

\section{Microbial effects on plant nutrient acquisition}

Rhizobacteria as PGPR can play an essential function in boosting plant nutrient acquisition by favouring elements that promote root biomass accumulation and/or inhibiting factors that could harm root system development. PGPR can play this role in two ways: indirectly (antagonism against infections) or directly (production of phytohormones, for example). Microorganisms can potentially influence plant nutrient acquisition processes by affecting nutrient availability in the rhizosphere and/or the performance of the biochemical systems that underpin the nutritional process [7].

Effects on rhizosphere nutrient availability Plant growth and productivity are strongly influenced by nutrient availability at the soil-root interface, which is influenced by a variety of factors such as soil type and chemical-physical characteristics, plant species and genotype, soil macro- and microorganism communities, and environmental conditions. The biological activity of both roots and microorganisms can be essential in this context [8].

In addition to a brief overview of the main mechanisms used by plants to acquire $\mathrm{N}, \mathrm{P}$, and Fe, the contribution of microbes to the dynamics of these three nutrients in the rhizosphere is described in the following sections; additionally, a review of the effects of PG-
PRs on physiological and molecular mechanisms underlying root nutrient acquisition will be presented in the following sections [9].

Plant-microbe-microbe interactions

Microbial activity in the rhizosphere is abundant, and it plays a significant role in biological and ecological processes that affect plant health. Understanding the involvement of bacteria in the wide range of processes and interactions that occur in the rhizosphere is critical for developing effective and reliable bio formulation [10].

The translocation pathways of PGPR bacteria appear to demand additional consideration when examined in the context of biocontrol. Bacterial colonisation of new settings relies heavily on motility on surfaces. Furthermore, host-adapted prokaryotes may benefit from the ability to move in a directed manner [11].

\section{Conclusion}

Because of current public worries about pesticide side effects, there is a growing interest in learning more about cooperative actions among rhizosphere microbial communities and how they might be used to agriculture. Certain cooperative microbial activities can be used as a low-input biotechnology and as the foundation for a strategy to aid in the development of sustainable, environmentally friendly practises that are critical to the stability and productivity of both agricultural and natural ecosystems.

A recent survey of both conventional and organic growers revealed an interest in adopting biological goods, implying that bioformulations' market potential will develop in the next years. The whole global market for synthetic pesticides, which was worth US $\$ 26.7$ billion in 2005 , is expected to drop to US $\$ 25.3$ billion in 2010. The global market for biopesticides, on the other hand, will grow from US\$ 672 million in 2005 to over US\$ 1 billion in 2010. While Europe is expected to lead the growth in biopesticide use with a 15 percent average annual growth rate (AAGR), Asia will be close behind with a 12 percent AAGR. 43.5 percent of sales in North America (including Mexico), 20.7 percent in Europe, 12.2 percent in Asia, 11.2 percent in Oceania (including Australia), 8.3 percent in Latin America (without Mexico), and 3.9 percent in Africa make up the global market. A full analysis on nitrogenfixing bacteria as biofertilizers, a market that is also increasing, is also included.

\section{Bibliography}

1. Valiente-Banuet A., et al. "Beyond species loss: the extinction of ecological interactions in a changing world". Functional Ecology 29 (2015): 299-307. 
2. Avellaneda Castro VA. "Evaluación agronómica del Rhizobium con inoculación y fertilización nitrogenada en una pastura de trébol blanco (Trifolium repens) y ryegrass perenne (Lolium perenne)". BS thesis (2007).

3. Williams JG., et al. “DNA polymorphisms amplified by arbitrary primers are useful as genetic markers". Nucleic Acids Research 18 (1990): 6531-6535.

4. Oleszek W and Stochmal A. "Triterpene saponins and flavonoids in the seeds of Trifolium species". Phytochemistry 61 (2002): 165-170.

5. Bordinave, G. Louis Pasteur (1822-1895) Microbes Infection 5.6 (2003) 553-560.

6. Reeve W., et al. "Complete genome sequence of Rhizobium leguminosarum bv trifolii strain WSM2304, an effective microsymbiont of the South American clover Trifolium polymorphum". Standards in Genomic Sciences 2 (2010): 66-76.

7. Watson LE., et al. "Molecular phylogeny of Old World Trifolium (Fabaceae), based on plastid and nuclear markers". Plant Systematics and Evolution 224 (2000): 153-171.

8. Admassie A and Matambalya FAST. "Technical efficiency of Small and Medium" (2002).

9. Bhattacharya P and Chakraborty G. "Current status of organic farming in India and other countries". Indian Journal of Fertilizers 1.9 (2005): 111-123.

10. Dwivedi Vandana. "Organic farming: Policy initiatives, National Seminar on National Policy on Promoting Organic Farming, 130-135". Scale Enterprises 9.6 (2005): 39-53.

11. Aneja KR. "Experiments in Microbiology. Plant Pathology and Tissue Culture" (2001): 471.

\section{Assets from publication with us}

- Prompt Acknowledgement after receiving the article

- Thorough Double blinded peer review

- Rapid Publication

- Issue of Publication Certificate

- High visibility of your Published work

Website: www.actascientific.com/

Submit Article: www.actascientific.com/submission.php

Email us: editor@actascientific.com

Contact us: +919182824667

Citation: Harsha Sharma and Avadhesh Kumar Koshal. "The Influence of Rhizobacteria that Promotes Growth of Plants on the Nutritional Acquisition Process". Acta Scientific Agriculture 6.1 (2022) 08-10. 